\title{
Calcarreous Fly Ash Content Signifacence To Self-Terminating Carbonation Model Of Concrete
}

\author{
Pawel Woliński ${ }^{1,{ }^{*}}$, Piotr Woyciechowski ${ }^{1}$, and Grzegorz Adamczewski ${ }^{1}$ \\ ${ }^{1}$ Warsaw University of Technology, Faculty of Civil Engineering, Al. Armii Ludowej 16 , \\ 00-637 Warsaw, Poland
}

\begin{abstract}
Calcareous Ely Ash is a combustion by-product of Brown coal. Its technical properties depend on the combustion conditions - in the paper calcareous fly ash obtained from the traditional grate furnaces is considered. The presented paper shows the results of accelerated carbonation tests according to the draft of CEN / TS 12390-12 standard. The obtained models have self-terminating character. Concretes of water to cement ratio (w/c) from 0,35 to 0,55 and Ely Ash to cement ratio ( $\mathrm{p} / \mathrm{c}$ ) from 0,2 to 0,5 were investigated.
\end{abstract}

\section{Introduction}

Due to a wide range of modern concrete applications, this material is exposed to many different types of interactions. The durability of concrete depends on its resistance to the impact of a given environment and it can be effectively shaped in particular at the material and technological stage [1]. Appropriate selection of concrete components quality and its composition, as well as performance conditions, such as the method of casting, compacting and, in particular, curing have a decisive impact on the durability of the final product. Due to the economic and ecological reasons it is justified to introduce waste components into the concrete, eg ashes. One of these types of additives is the low-calcium fly ash, which is not explicitly normalized in Poland with regard to concrete use. Fly ash limestone (W) is defined as "a very fine dust, having hydraulic and / or pozzolanic properties. It consists essentially of reactive calcium oxide $(\mathrm{CaO})$, reactive silicon dioxide $(\mathrm{SiO} 2)$ and aluminum oxide $\left(\mathrm{Al}_{2} \mathrm{O}_{3}\right)$. The residue contains iron oxide $\left(\mathrm{Fe}_{2} \mathrm{O}_{3}\right)$ and other compounds" [2]. PN-EN 206: 2014-04 [3] standard defines many different aggressive environments described in exposure classes. Among them, particular importance undoubtedly should be attributed to the impact of atmospheric $\mathrm{CO}_{2}$ - resulting in the phenomenon of carbonation of concrete [4,5]. This phenomenon is accompanied by a gradual lowering of the $\mathrm{pH}$ of the concrete progressing slowly from the outside of the element towards the core. The concrete layer in which this process took place, i.e. where the $\mathrm{pH}$ value fell below a certain limit, is considered to be a carbonated zone. The rate of carbonation depends on many factors: the ratio of water to cement ( $\mathrm{w} / \mathrm{c}$ ), $\mathrm{CO}_{2}$ exposure time, concrete moisture, free content of lime, i.e. reaction capable, in cement stone, etc. Steel reinforcement in concrete environment is protected against corrosion if concrete it is not contaminated with aggressive substances in relation to

\footnotetext{
*Corresponding author: g.adamczewski@il.pw.edu.pl
} 
steel, and its $\mathrm{pH}$ is high enough to ensure durability of so-called a passive film on the reinforcement surface. The passive film on the surface of the steel is formed thanks to the alkaline environment inside the concrete and is stable up to the $\mathrm{pH}$ level around $10-11$. The $\mathrm{pH}$ of the concrete may, however, change during time. When concrete is hardened the excess mixing water can allow carbon dioxide from the atmosphere surrounding the building element to diffuse into the existing fine pores of the concrete. The reaction of carbon dioxide with calcium hydroxide leads to the formation of calcium carbonate, $\mathrm{CaCO}_{3}$. When the carbonation front reaches the surface of the steel reinforcement, the passive layer protecting against corrosion disappears. When there is enough water and oxygen, the steel corrosion process begins.

\section{Potential of using fly ash in cement composites}

In Poland, fly ash is formed primarily in the Bełchatów Power Plant, but even a product from this one source has a high variability of chemical and physical properties. Despite the above, addition of this fly ash to cement in an amount up to $30 \%$ provides high strength after 90 days of hardening, including a significant increase between 28 and 90 days. It is believed that after treatment, fly ash is a valuable mineral supplement for the production of cement [9] and is therefore currently used in this field.

The PN EN 197-1 [2] standard distinguishes four types of cements in which fly ash designated in the cement composition with the letter $\mathrm{W}$ is used:

1) Portland multi-component ash cement (CEM II / A-W and CEM II / B-W);

2) multi-component mixed Portland cement (CEM II / A-M and CEM II / B-M);

3) pozzolanic cement (CEM IV / A and CEM IV / B);

4) multi-component cement (CEM V / A and CEM V / B).

They may contain various, depending on the cement type, amount of W lime ash (from 6 to $35 \%$, and in some cases even up to $55 \%$ ) [3].

An important direction for the use of fly ash in the production of building materials may also be the production of light aggregates. Although numerous production technologies for such aggregates have been developed, their production has not yet been developed on a larger scale. It is probably influenced by their relatively high price and too weak product promotion [4].

Other applications of calcareous fly ash include:

1) production of dry mortars,

2) strengthening of native soil and construction of road embankments,

3) hygienization of sewage sludge,

4) completion and reclamation of areas adversely affected by mining activities.

As the addition in concrete, fly ash is not standardized in Europe, which is due to the fact that it is still not a material well researched in the context of such use. Accordingly, the possible production of concrete with fly ash limestone should be carried carefully and with attention given to the issues of concrete rheology and in particular the problems associated with the deterioration of fluidity mix, loss of consistency, as well as the compatibility issues in a binder-additive-admixture system.

The potential limitation of the use of ash as a component of concrete may also be associated with unfavorable aspects of its impact on durability. The influence of fly ash on the durability of concrete limestone is an issue not widely discussed in the literature, in comparison with the impact of the siliceous fly ashes and opinions on this matter are sometimes divergent. Addition of this type of fly ash, which belongs according to ASTM classification [5] to a class $C$ causes that the concrete has a very low permeability to water and solutions containing chlorine compounds, if used as a complement of the finest aggregate fraction and not as a replacement of cement [6]. Similarly, the introduction of lime to fly ash 
cement composition (ie. As a substitute for part of the clinker) increases the resistance of mortars permeability to chloride ions [7]. According to Dąbrowska [7], this resistance increases with increasing amounts of lime fly ash in concrete composition, extension of the period of curing and the application of lime fly ash activated mechanically (milling significantly increases the activity of the ash).

When replacing part of the cement with fly ash, the compressive strength of the concrete decreases, especially in early hardening period. During the hardening (28 days and longer) concrete with the addition of fly ash achieves strengths similar to or even higher than concrete without ash content [6].

The concrete in which a significant part of the cement was replaced by fly ash may have low resistance to frost. The main reason for the reduction in frost resistance is the slow course of pozzolanic reaction and the low rate of strength increase in concrete. Proper curing of cement-ash concretes aged for a longer period may reduce this decrease [6].

Cement with the addition of calcareous fly ash increases the susceptibility of mortars to carbonation, especially at its higher content in the cement composition. The depth of carbonation is lower for mortars with extended moisture curing in the initial hardening period [7].

Dąbrowska [7] has also investigated the influence of calcareous fly ash on the sulfate corrosion resistance solutions such as $\mathrm{Na}_{2} \mathrm{SO}_{4}, \mathrm{MgSO}_{4},\left(\mathrm{NH}_{4}\right) 2 \mathrm{SO}_{4}$ and the mixture of $\mathrm{Na}_{2} \mathrm{SO}_{4}$ and $\mathrm{MgSO}_{4}$ and in artificial sea water. An adverse influence of calcareous ash was found in the case of contents up to approx. $30 \%$ of cement. Only 50\% addition of fly ash to the cement composition allows to limit the expansion and decreases in compressive strength of mortars in each of the aggressive solutions, compared to Portland reference mortars CEM I. Introduction to the cement composition of fly ash in combination with another main component cement (ie granulated blast-furnace slag or silica fly ash) allows to increase cement resistance to sulfate corrosion and permeability of chloride ions. There is a noticeable synergic effect between these mineral components, especially at their higher content in the cement composition.

\section{Modification of concrete with fly ash and a carbonation of concrete}

Evaluation of the carbonation of concretes containing fly ash should take into account the microstructure of the hardened cement paste, since fly ash binds a part of $\mathrm{Ca}(\mathrm{OH})_{2}$ as a result of pozzolanic reaction. As a result, the content of calcium hydroxide, which is capable of reacting with atmospheric carbon dioxide, is lower, thus the carbonation depth may be higher, since the same amount of $\mathrm{CO}_{2}$ is sufficient to carbonate a larger area of concrete, according to Neville [8] on the basis of Bier's research [9]. These studies show that the depth of carbonation is higher when the content of $\mathrm{Ca}(\mathrm{OH})_{2}$ in the cement paste is lower. It follows that the presence of fly ash can accelerate the process of carbonation and move the carbonation front into the concrete. However, there is also an opposite effect, associated with the formation of a more compact microstructure of the hardened paste with ashes, which reduces the diffusivity and the limits the rate of carbonation. It can therefore be concluded that the effect of fly ash on the course of carbonation consists of two opposite effects: accelerating - associated with the deficiency of $\mathrm{Ca}(\mathrm{OH})_{2}$ used for the pozzolanic reaction, whose carbon dioxide diffuses is "searching" deeper in the concrete; • inhibitory - associated with the structure sealing by fine grain ash and additional pozzolanic reaction products. The results of the published studies do not resolve unequivocally [10], which effect is dominating. It depends on the interaction of ingredients and external factors, however, one of the most important factors is curing. Proper concrete curing is essential for pozzolanic reactions to 
take place with the formation of a tight structure. It was found that badly cured ash concrete is very rapidly carbonating and poor curing of concretes with mineral additives after a year of exposure in the urban atmosphere resulted in a very large carbonation depth, reaching around $20 \mathrm{~mm}$. Properly cured B30 (C25/30) concretes, made using cement with $30 \%$ admixture of fly ash, showed only about $1 \%$ greater depth of carbonation in comparison with concretes of the same class from Portland cement [11].

The method of introducing ashes into the concrete mix, ie whether the additive is introduced as a substitute for part of the cement or as an increase in the amount of binder, is also important. In the first case, the effect of the $\mathrm{Ca}(\mathrm{OH})_{2}$ deficit increases, in the second the role of the sealing effect. There are not too many data in the publications on carbonation testing of concretes with lime ashes. The high content of free lime in the ash may suggest that the initial availability of $\mathrm{Ca}(\mathrm{OH})_{2}$ for the carbonation reaction will be high, especially that the free lime in these ashes is particularly reactive [6]. One can therefore expect a large initial rate of carbonation. On the other hand, the intense course of the pozzolanic reaction will deplete the available calcium hydroxide, while filling the porosity structure with the products of this reaction, which should reduce the $\mathrm{CO}_{2}$ diffusion capacity and inhibit the course of carbonation.

\section{Formulation of finite carbonation model for concretes with calcareous fly ash}

To formulate the model, an element of the equation ( 1 / sqrt (t)) was used, which determines the hyperbolic character of the carbonation function. Woyciechowski [12] presented the general model of carbonation in the form of:

$$
\mathrm{h}=\mathrm{a}-\mathrm{b}^{*}(1 / \operatorname{sqrt}(\mathrm{t}))
$$

where: $\mathrm{h}$ - carbonation depth $\mathrm{a}, \mathrm{b}$ - material and technological factors $\mathrm{t}$ - exposure time

In the general form of the model (1) it was assumed that the carbonation depth $\mathrm{h}$ is a function of the inverse of the element from the time of carbonation:

$$
\mathrm{h}=\mathrm{f}(1 / \mathrm{sqrt}(\mathrm{t}))
$$

The model was developed for each of the examined compositions in a detailed form (1).

The free expression of the function (a) for each case (composition) is expressed in a complex form (3), so that its dependence on the constants $\mathrm{w} / \mathrm{c}$ and $\mathrm{p} / \mathrm{c}$ in the given composition is visible.

$$
\mathrm{a}=\mathrm{A}+\mathrm{B} *(\mathrm{w} / \mathrm{c})+\mathrm{C}^{*}(\mathrm{p} / \mathrm{c})
$$

The research program assumed, for technological and practical reasons, values of the w/c ratio from 0.35 to 0.55 and $\mathrm{p} / \mathrm{c}$ from 0.20 to 0.50 . The calculated values of the above coefficients for the experiment plan were determined for five intermediate input values $\mathrm{x} 1$ and $x 2$, determined for conventional values xi of $0, \pm 1, \pm 1,414$ (Table 2). The research program was developed in the form of a two-factor, partial-rotal-quasi-uniformal plan with a double repetition at the central point. The plan was considered optimal due to three criteria of selection, ie the criterion of implementation, informativeness and efficiency. 
Table 1. List of real and code variables of the series of the experiment plan

\begin{tabular}{|c|c|c|c|c|}
\hline \multirow{2}{*}{$\begin{array}{c}\text { Nr. Of } \\
\text { series }\end{array}$} & \multicolumn{2}{|c|}{ Coded values } & \multicolumn{2}{c|}{ Real variables } \\
\cline { 2 - 5 } & $\mathbf{x 1}$ & $\mathbf{x 2}$ & $\mathbf{x 1}^{\wedge} \mathbf{( w / c )}$ & $\mathbf{x 2}^{\wedge}(\mathbf{p} / \mathbf{c})$ \\
\hline 1 & -1 & -1 & 0.379 & 0.24 \\
\hline 2 & 1 & 1 & 0.521 & 0.46 \\
\hline 3 & -1.414 & 0 & 0.35 & 0.35 \\
\hline 4 & 1.414 & 0 & 0.55 & 0.35 \\
\hline 5 & 0 & -1.414 & 0.45 & 0.20 \\
\hline 6 & 0 & 1.414 & 0.45 & 0.50 \\
\hline 7 & 0 & 0 & 0.45 & 0.35 \\
\hline 8 & -1 & 1 & 0.379 & 0.46 \\
\hline 9 & 1 & -1 & 0.521 & 0.24 \\
\hline 10 & 0 & 0 & 0.45 & 0.35 \\
\hline
\end{tabular}

\section{Results}

The Portland cement CEM I 32.5 R (compliant with PN-EN 197-1: 2012 [2]), tap water in accordance with PN-EN 1008: 2004 [13], and aggregate of 0/2 mm fraction (river sand) and gravel 2/8 mm, 8/16 mm, in accordance with PN-EN $12620+\mathrm{A} 1: 2010$ [14] were used for the tests. Calcareous ash used for research came from the Bełchatów power plant. The compositions of concrete mixes are given in Table 2.

Accelerated test of resistance to carbonation of concrete was carried out according to the procedure given in the draft standard EN 12390-12 [15]. The test is performed on a minimum of 2 samples with dimensions $100 \mathrm{~mm} \times 100 \mathrm{~mm} \times 500 \mathrm{~mm}$. The result of the test is the average of 20 measuring points. The samples were matured after curing not less than 42 days from the date of forming - including one day covered in the mould, 27 days in water and 14 days in laboratory conditions ( $\mathrm{RH} 50 \div 65 \%, \mathrm{~T}=18 \div 250 \mathrm{C}$ ), dried to constant weight. Carbonation took place in a hermetic carbonation chamber in an environment that meets the following conditions: forced air circulation with $\mathrm{CO}_{2}$ concentration $=(4 \pm 0.5) \%$, $\mathrm{T}$ temperature $(20 \pm 2) 0^{\mathrm{C}}, \mathrm{RH}=(55 \pm 5) \%$. The basic exposure time is 70 days. In the case of the presented tests, the study was carried out after 28,56, 70 and 90 days of exposure. To determine the depth of carbonation, a phenolphthalein solution $(1 \mathrm{~g}$ phenolphthalein dissolved in $70 \mathrm{~g}$ ethanol and then diluted with $30 \mathrm{~g}$ distilled water) was used. The solution was sprayed on a fresh cross-section of the sample and the colour change to violet after about 60 minutes was observed.

Table 2. Quantification of components ( $\mathrm{kg}$ ) per $1 \mathrm{~m} 3$ of concrete mixes

\begin{tabular}{|c|c|c|c|c|c|c|c|c|}
\hline \multirow{2}{*}{$\begin{array}{l}\text { Component } \\
\text { Nr. of } \\
\text { composition }\end{array}$} & \multirow{2}{*}{$\begin{array}{c}\text { Cement, } \\
\mathrm{kg}\end{array}$} & \multirow{2}{*}{$\begin{array}{c}\text { Water, } \\
\text { kg }\end{array}$} & \multirow{2}{*}{$\begin{array}{c}\text { Aggregate, } \\
\text { kg }\end{array}$} & \multirow{2}{*}{$\begin{array}{c}\text { Fly } \\
\text { ash, kg }\end{array}$} & \multirow[t]{2}{*}{$\mathbf{w} / \mathbf{c}$} & \multirow[t]{2}{*}{$\mathbf{p} / \mathbf{c}$} & \multicolumn{2}{|c|}{$\begin{array}{c}\text { Superplasticizer } \\
\% \text { of cement } \\
\text { mass }\end{array}$} \\
\hline & & & & & & & $\mathbf{A}$ & B \\
\hline 1 & 361.2 & 137 & 1872.2 & 88.1 & 0.379 & 0.244 & 1.50 & 2.49 \\
\hline 2 & 299.6 & 156 & 1817.6 & 136.6 & 0.521 & 0.456 & 1.03 & 0 \\
\hline 3 & 338.6 & 118.5 & 1904.4 & 118.5 & 0.35 & 0.35 & 1.50 & 2.20 \\
\hline 4 & 317.3 & 174.5 & 1784.6 & 111.0 & 0.55 & 0.35 & 0.12 & 0 \\
\hline 5 & 363.3 & 163.5 & 1816.6 & 72.6 & 0.45 & 0.2 & 1.44 & 0 \\
\hline
\end{tabular}




\begin{tabular}{|c|c|c|c|c|c|c|c|c|}
\hline $\mathbf{6}$ & 297.8 & 134 & 1861.1 & 148.8 & 0.45 & 0.5 & 1.50 & 1.80 \\
\hline $\mathbf{7}$ & 327.3 & 147.3 & 1841.2 & 114.5 & 0.45 & 0.35 & 1.50 & 1.44 \\
\hline $\mathbf{8}$ & 312.4 & 118.5 & 1895.5 & 142.5 & 0.379 & 0.456 & 1.50 & 2.55 \\
\hline $\mathbf{9}$ & 343.8 & 179 & 1781.6 & 83.5 & 0.521 & 0.244 & 0.48 & 0 \\
\hline $\mathbf{1 0}$ & 327.3 & 147.3 & 1841.2 & 114.5 & 0.45 & 0.35 & 1.50 & 1.44 \\
\hline
\end{tabular}

In total, under accelerated carbonation conditions, 9 concrete compositions were analyzed mathematically and with different $\mathrm{w} / \mathrm{c}$ ratios and $\mathrm{p} / \mathrm{c}$ ratios determined according to the experiment plan, obtaining a very good agreement of results with a hyperbolic model in the form of

$$
\mathrm{h}=\mathrm{A}+\mathrm{B} *(\mathrm{w} / \mathrm{c})+\mathrm{C} *(\mathrm{p} / \mathrm{c})+\mathrm{b} / \mathrm{sqrt}(\mathrm{t})
$$

The correlation coefficients of hyperbolic models were developed on the basis of averages of measurements indicate a good match of the adopted hyperbolic model to the results of laboratory tests obtained under accelerated carbonation conditions $(\mathrm{R}=0.85-0.99)$ regardless of the accepted range of material and technological variables (tab. 3). The adequacy of the actual course of the phenomenon and models obtained using the measurement averages is confirmed by the fact that in all measurement series the variability index of results did not exceed $10 \%$. A wide range of material and technological variables adopted in the conducted experiments and high statistical compliance of experimental results with the tested general carbonation model and small dispersion of measurement results in the series of measurements allow to accept as true thesis that the process of carbonation is finite in the concrete space, and to the mathematical description changes in the range of carbonation can be used in the carbonation model, which is a hyperbola, the asymptote of which is the maximum range of carbonation. The basis for the adoption of the hyperbolic model is the recognition of the carbonation process to be finite in time as a result of the self-limiting nature of the phenomenon, due to the gradual decrease of the $\mathrm{CO}_{2}$ diffusion rate and the rate of carbonation aspiring asymptotically to zero. The maximum carbonation depth $\mathrm{h}_{\max }$ is the asymptote of the hyperbolic function with the equation:

$$
h_{\text {max }}=\lim _{t \rightarrow \infty} h\left(\frac{w}{c} ; \frac{p}{c} ; t\right)=a+b *\left(\frac{w}{c}\right)+c *\left(\frac{p}{c}\right)
$$

\begin{tabular}{|c|c|c|c|}
\hline $\begin{array}{c}\text { Nr. Of } \\
\text { compositio } \\
n\end{array}$ & $\begin{array}{c}\text { Model of carbonation, } h, t-\text { depth and time of } \\
\text { carbonation }\end{array}$ & $\begin{array}{l}\text { Ordinate of the } \\
\text { asymptote, } \mathrm{mm}\end{array}$ & $\begin{array}{l}\text { Coefficient of } \\
\text { correlation, } \mathrm{R}\end{array}$ \\
\hline $\begin{array}{c}1 \\
w / c=0.379 \\
\mathrm{p} / \mathrm{c}=0.24\end{array}$ & $\begin{array}{c}h=(7.500938)+(2.907884) * 0.379+(1.878495) \\
* 0.24+(-27.1548) / \operatorname{sqrt}(t)\end{array}$ & 9.04 & 0.96 \\
\hline $\begin{array}{c}2 \\
\mathrm{w} / \mathrm{c}=0.521 \\
\mathrm{p} / \mathrm{c}=0.46\end{array}$ & $\begin{array}{c}h=(9.74987)+(5.126820) * 0.521+(4.538526) * \\
0.46+(-54.3055) / \operatorname{sqrt}(t)\end{array}$ & 14.49 & 0.93 \\
\hline $\begin{array}{c}3 \\
\mathrm{w} / \mathrm{c}=0.35\end{array}$ & & 2.25 & 0.62 \\
\hline
\end{tabular}

Table 3. List of models of carbonation in accelerated conditions 


\begin{tabular}{|c|c|c|c|}
\hline $\mathrm{p} / \mathrm{c}=0.35$ & $\begin{array}{c}h=(1.769975)+(0.686727) * 0.35+(0.686727) * \\
0.35+(-8.35332) / \operatorname{sqrt}(t)\end{array}$ & & \\
\hline $\begin{array}{c}4 \\
\mathrm{w} / \mathrm{c}=0.55 \\
\mathrm{p} / \mathrm{c}=0.35\end{array}$ & $\begin{array}{c}h=(12.31813)+(6.822073) * 0.55+(4.378277) * \\
0.35+(-65.9656) / \operatorname{sqrt}(t)\end{array}$ & 17.59 & 0.96 \\
\hline $\begin{array}{c}5 \\
\mathrm{w} / \mathrm{c}=0.45 \\
\mathrm{p} / \mathrm{c}=0.2\end{array}$ & $\begin{array}{c}h=(10.88112)+(4.954678) * 0.45+(2.258276) * \\
0.20+(-50.5864) / \operatorname{sqrt}(t)\end{array}$ & 13.56 & 0.94 \\
\hline $\begin{array}{c}6 \\
\mathrm{w} / \mathrm{c}=0.45 \\
\mathrm{p} / \mathrm{c}=0.5\end{array}$ & $\begin{array}{c}h=(9.372020)+(4.274658) * 0.45+(4.738282) * \\
0.50+(-50.3489) / \operatorname{sqrt}(t)\end{array}$ & 13.66 & 0.92 \\
\hline $\begin{array}{c}7 \\
\mathrm{w} / \mathrm{c}=0.45 \\
\mathrm{p} / \mathrm{c}=0.35\end{array}$ & $\begin{array}{c}h=(7.701497)+(3.522767) * 0.45+(2.762448) * \\
0.35+(-37.2595) / \operatorname{sqrt}(t)\end{array}$ & 10.25 & 0.85 \\
\hline $\begin{aligned} & 8 \\
& w / c=0.379 \\
& p / c=0.46\end{aligned}$ & $\begin{array}{c}h=(2.424346)+(0.983052) * 0.379+(1.171441) \\
* 0.46+(-11.5269) / \operatorname{sqrt}(t)\end{array}$ & 3.33 & 0.99 \\
\hline $\begin{aligned} & 9 \\
& \mathrm{w} / \mathrm{c}= 0.521 \\
& \mathrm{p} / \mathrm{c}=0.24\end{aligned}$ & $\begin{array}{c}h=(11.88171)+(6.240330) * 0.521+(2.929116) \\
* 0.24+(-60.4545) / \operatorname{sqrt}(t)\end{array}$ & 15.83 & 0.94 \\
\hline
\end{tabular}

\section{Conclusions}

The study has shown that the calcareous ash used in the research as a substitute for aggregates in the amount of 20 to $50 \%$ of cement allowed to obtain concrete with very low carbonation depth (from 7 to $9 \mathrm{~mm}$ after 70 days in $4 \% \mathrm{CO}_{2}$ concentration), further indicate that with constant cement content and $\mathrm{w} / \mathrm{c}$ value, there is an optimal ash content, leading to a lower susceptibility to carbonation. The dynamics of the carbonation depth development changes in the case of an increase in the ash content - the intensive progress of the process is noticed until the 56th day of carbonation, if the ash content is high.

\section{References}

1. M. Thomas, Portland Cement IS548 (2007)

2. PN-EN 197-1 (2012)

3. Z. Giergiczny, Popiół lotny w składzie cementu i betonu (WPŚ, Gliwice, 2013)

4. K. Galos, A. Uliasz-Bocheńczyk, Gosp. Sur. Min.21(1), 23-42 (2005)

5. ASTM C618-15 (2015)

6. Z. Giergiczny, Rola popiołów lotnych wapniowych i krzemionkowych w ksztaltowaniu właściwości wspótczesnych spoiw budowlanych $i$ tworzyw cementowych, 325, (Politechnika Krakowska, Kraków, 2006) 
7. M. Dąbrowska, Wpływ PLW na odporność korozyjna kompozytów wykonanych $z$ cementu portlandzkiego wielosktadnikowego (Rozpr. Dokt., Politechnika Śląska, 2014)

8. A.M. Neville, Właściwości betonu (Stowarzyszenie Producentów Cementu, Kraków, 2012)

9. Th. A. Bier, Materials Research Society Symposium 85, 123-34 (1987)

10. J.A. Bogas, S. Real, B. Ferrer, Cem. Concr. Comp. 71, 110-121 (2016)

11. Zastosowanie popiołów lotnych z kottów fluidalnych $w$ betonach konstrukcyjnych, (IPPT PAN, Warszawa, 2010)

12. P. Woyciechowski, Prace naukowe budownictwo 157, (Oficyna wydawnicza PW, Warszawa, 2013)

13. PN-EN 1008 (2004)

14. PN-EN $12620+\mathrm{A} 1(2010)$

15. EN 12390-12 (2010) 